\title{
Hubungan motivasi dengan keterampilan smash dalam permainan bola voli
}

\section{Relationship motivation with smash skills in volleyball games}

\author{
Sony Hasmarita ${ }^{1}$, Ahmad Husaeni ${ }^{2}$ \\ 1.2 Program studi PJKR, STKIP Pasundan, Cimahi, Jawa Barat, 40512,Indonesia
}

\begin{abstract}
ABSTRAK
Penelitian yang dilakukan oleh penulis adalah penelitian mengenai Hubungan Motivasi Dengan Keterampilan Smash Dalam permaianan Bola Voli . Penelitian ini didasari pada permasalahan ada atau tidaknya suatu hubungan motivasi siswa dengan keterampilan smash bola voli. Metode yang digunakan dalam penelitian ini yaitu deskriptif dengan pendekatan korelasi. Dengan teknik sampel purposiv sampling, dalam penelitian ini untuk teknik pengumpulan data peneliti menggunakan tes untuk keterampilan smash dengan instrumen gerak yang sudah disediakan, untuk motivasi mengunakan angket. Populasi yang digunakan dalam peneltian ini yaitu seluruh siswa putra SMPN 1 Saguling yang mengikuti ekstrakulikuler bola voli sebanyak 53 orang. Dan sampel dalam penelitian ini adalah siswa putra kelas VII yang mengikuti ekstrakulikuler bola voli yang berjumlah 30 orang. Berdasrkan data penelitian hasil signifikan $r$ hitung dengan signifikan $0,000<$ 0,05, maka Ho ditolak dan Hi diterima, dan nilai person correlation 0,812 dengan kategori Korelasi Kuat yang berarti ada pengaruh nyata ( signifikan) variabel Motivasi (x) terhadap keterampilan smash bola voli (y) Dengan nilai determinasi sebesar 66,0\% dari variabel motivasi (x) dengan variabel smash (y). ) kesimpulan dari penelitian ini menjelaskan bahwa motivasi sangat berhubungan dengan keterampilan smash bola voli dan motivasi memepengaruhi keterampilan smash dalam kategori cukup tinggi.
\end{abstract}

Kata kunci : motivasi, keterampilan smash bola voli, permainan bola

\begin{abstract}
Research conducted by the author is a study of the Relationship between Motivation and Smash Skills in Volleyball Games. This research is based on the problem of whether or not there is a relationship between student motivation and volleyball smash skills. The method used in this research is descriptive with the correlation approach. With a purposive sampling technique, in this study the researchers used data collection techniques to test smash skills with the provided motion instruments, for motivation using a questionnaire. The population used in this research are all male students of SMPN 1 Saguling who take volleyball extracurricular as many as 53 people. And the sample in this study was male students of class VII who took volleyball extracurricular totaling 30 people. Based on the research data, the result of $r$ count is significant with $0.000<0.05$, then Ho is rejected and Hi is accepted, and the person correlation value is 0.812 with the category of Strong Correlation which means that there is a significant (significant) influence of Motivation variable $(x)$ on volleyball smash skills $(y)$ With a determination value of $66.0 \%$ of the motivation variable $(x)$ with a smash variable (y). ) the conclusion of this study explains that motivation is highly correlated with volleyball smash skills and motivation influences smash skills in the quite high category.
\end{abstract}

Keywords: motivation, volleyball smash skills, volleyball game 



\section{PENDAHULUAN}

Keterampilan smash atau bisa di sebut spike, merupakan teknik pukulan dengan tujuan untuk mematikan permainan lawan, yang dilakukan dengan cara memukul bola dari atas net. Sedangkan keterampilan itu sendiri adalah suatu kecakapan dalam melakukan tugas, terutama dalam melakukan tugas gerak. (Sugiarto, 2012) Istilah keterampilan itu sendiri juga memiliki beberapa pengertian dan telah di pakai dalam beberapa versi dalam literatur tentang perilaku motorik. Yang lazim di pakai ialah, keterampilan di pandang sebagai suatu perbuatan atau tugas dan lainnya adalah sebuah indikator dari tingkat kemahiran. Jika suatu keterampilan di pandang sebagai aksi motorik atau pelaksanaan suatu tugas, keterampilan itu akan terdiri dari sejumlah respons motorik dan persepsi yang diperoleh melalui belajar.

(Achmad, 2016); Keterampilan akan didapatkan melalui proses belajar yang tidak mudah menyerah sehingga akan menghasilkan suatu hasil yang memuaskan memperoleh ketrampilan yang di harapkan. Dari pemaparan di atas dapat di simpulkan bahwa bahwa keterampilan adalah sesuatu yang harus dipelajari,secara konsisten dan bersifat spesifik untuk melaksanakan suatu tugas tertentu. (Sulistiadinata, 2020) Bola voli merupakan permainan yang mengandung unsur kekuatan, kecepatan, dan kelenturan. Setiap cabang olahraga mempunyai cara dan karakteristik tersendiri, begitu pula dengan permainan bola voli.

Menurut (Yuniawan, 2012) Dalam permainan bola voli secara garis besar ada 4 unsur dasar teknik yang harus di kuasai, teknik dasar yang harus di kuasai antara lain. 'servis, passing (operan), bloking (bendungan), smash (serangan). Penguasaan teknik dasar terhadap keterampilan bermain bola voli sangatlah penting, sebagai penunjang saat bermaian. Sedangkan (Pranopik, 2017); menyatakan bahwa Permainan bola voli adalah permainan yang dimainkan oleh dua tim, yang masing-masing tim berjumlah 6 orang, setiap pemain memiliki keterampilan khusus yakni sebagai pemukul,pengumpan, dan libero.

Pendapat lain (Imaw ati, Clarry Sada, 2014); menyatakan bahwa Permainan bola voli adalah olahraga yang dimainkan oleh 2 tim yang mana masing-masing tim terdiri dari 6 orang pemain. sedangkan Menurut Cimenli, Ozkan 2016 dalam (Rohendi, 2019) Bola voli adalah suatu olahraga beregu yang dimainkan oleh dua regu yang masingmasing terdiri dari enam orang tiap regunya yang dipisahkan oleh net.

Akan tetapi yang menjadi bahan pengamatan bagi penulis, pada penelitian ini adalah terfokus pada keterampilan smash mengingat pentingnya keterampilan smash dalam permainan bola voli, terlepas dari beberapa macam teknik dasar yang ada dalam 
permainan bola voli itu sendiri. (Primayanti, 2016) Pukulan smash merupakan teknik dasar yang harus dikuasai pemain, karena dengan cara yang cepat, tajam dan terarah, seorang pemain dapat mematikan lawan untuk memperoleh nilai dengan mudah. Dari pemaparan di atas dapat di ambil kesimpulan bahwa Smash dalam permainan bola voli merupakan suatu teknik yang bisa menghasilkan point dalam suatu pertandingan, dan merupakan teknik utama dalam melakukan serangan ke daerah lawan.

Smash merupakan bentuk serangan yang paling banyak di pergunakan dalam upaya memperoleh nilai suatu tim, seorang penyerang atau smasher seharusnya menguasai teknik ini dengan baik, karena teknik smash sangat efektif untuk mematikan bola di lapangan lawan. Berdasarkan pengamatan peneliti ketika melakukan observasi ke sekolah smpn 1 saguling. Penulis menemukan beberapa permasalahan, dalam proses pembelajaran materi smash dalam permaianan bola voli pada pelajaran penjas, penulis melihat masih banyak siswa siswi yang kurang memiliki motivasi, dalam mengikuti pembelajaran bola voli. Terlihat dari kurangnya ketekunan dalam belajar kurangnya minat kurangnya perhatian dan lain-lain.

Berdasarkan beberapa faktor yang dikemukakan di atas, sehingga mendorong penulis untuk melakukan penelitian lebih lanjut mengenai hubungan motivasi dengan keterampilan smash. Mengingat begitu sulitnya teknik smash itu sendiri, karena memiliki gerakan yang komplek yang terdiri dari. (Kemal, 2011) langkah awalan, 2) tolakan untuk meloncat, 3) memukul bola saat melayang di udara dan, 4) saat mendarat kembali setelah memukul bola.

\section{METODE}

Jenis penelitian yang di gunakan dalam penelitian ini adalah penelitian Deskriptif dengan pendekatan korelasional. (Sugiono, 2014) Penelitian deskriptif adalah metode yang digunakan untuk menggambarkan atau menganalisis suatu hasil penelitian tetapi tidak digunakan untuk membuat kesimpulan yang lebih luas. Metode deskriptif korelasional dalam penelitian ini bertujuan untuk mengetahui Hubungan motivasi dengan keterampilan smash dalam permianan bola voli. Adapun rancangan dalam penelitian ini sebagai berikut:

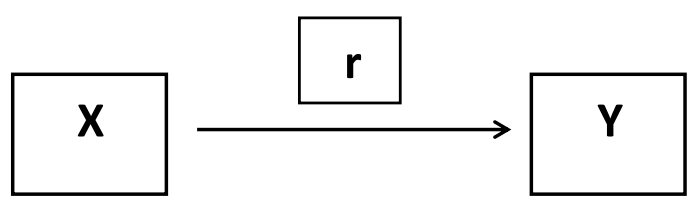

\section{Gambar 1. Desain Penelitian}

Populasi dalam penelitian ini adalah seluruh siswa SMPN 1 Saguling yang mengikuti ektrakulikuler bola voli yang terdiri dari 53 orang siswa. Teknik pengambilan 
sampel yg di pergunakan dalam penelitian ini adalah teknik sampling purposive. (Sugiono, 2015); Purposive sampling adalah teknik pengambilan sample sumber data dengan pertimbangan tertentu. Adapun sampel pada penelitian ini adalah siswa putra kelas VII yang mengikuti ekstrakuliker bola voli yang terdiri dari 30 siswa. Untuk menganalisis data dalam penelitian ini mengunakan uji korelasi regresi sederhana denagn taraf signifikansi 0,05, sebelum melakukan uji korelasi, sebagai syarat memenuhi persyaratan analisis data terlebih dlu melakukan uji normaitas dan linieritas setelah di lakukan pengujian menunjukan adanya interaksin Maka dilanjutkan dengan uji korelasi.

\section{HASIL DAN PEMBAHASAN}

\section{Hasil}

Hasil penelitian yang diperoleh oleh peneliti dideskripsikan secara rinci untuk masing-masing variabel. Pembahasan variabel dilakukan dengan menggunakan data kuantitatif, yaitu data yang diolah berbentuk angka atau skor yang kemudian ditafsirkan secara deskriptif:

Tabel 1. Hasil Uji Normalitas

\begin{tabular}{llr}
\hline \multicolumn{2}{c}{ One-Sample Kolmogorov-Smirnov Test } \\
\hline $\mathrm{N}$ Normal Parameters ${ }^{\mathrm{a}, \mathrm{b}}$ & Mean & 30 \\
& Std. Deviation &, 0000000 \\
Most Extreme & Absolute & 3,71791293 \\
Differences & Positive &, 087 \\
& Negative &, 087 \\
Test Statistic & &,- 063 \\
Asymp. Sig. (2-tailed) & &, 087 \\
\end{tabular}

Berdasarkan tabel 1 di atas Perhitungan menggunakan spss 25, dari data yang diambil maka jika nilai signifikan $>0,05$ maka data tersebut berdistribusi normal, dan sebaliknya jika nilai signifikan $<0,05$ maka data tersebut berdistribusi tidak normal. Berdasarkan output di atas bahwa nilai signifikan sebesar 0,200>0,05 maka dapat disimpulkan bahwa data yang di uji berdistribusi normal.

\section{Tabel 2. Hasil Uji Determinasi}

\begin{tabular}{lllll}
\hline Model Summary & & & \\
\hline & & & \\
& & & Std. Error of the \\
Model $\quad \mathrm{R}$ & R Square & Adjusted R Square & Estimate \\
1 &, $812^{\mathrm{a}}$ &, 660 &, 648 & 3,78372 \\
\hline a. Predictors: (Constant), Motivasi & & \\
\hline
\end{tabular}

Berdasarkan tabel 2 di atas Perhitungan mengunakan spss 25, dari data yang diambil berdasrkan uji determinasi di ketahui bahwa $\mathrm{R}$ square sebesar 0,660 nilai ini mengandung arti bahwa pengaruh motivasi $(\mathrm{X})$ terhadap keterampilan smash bola voli (y) 
adalah sebesar 66,0 \% sedangkan 34,0\% keterampilan smash di pengaruhi oleh variabel yang lain yang tidak diteliti.

Tabel 3. Hasil perhitungan koefisien Korelasi

\begin{tabular}{llll}
\hline Correlations & & & \\
\hline & & & \\
& & Motivasi & $\begin{array}{l}\text { Keterampilan } \\
\text { smash } \\
\text { Motivasi }\end{array}$ \\
& Pearson Correlation & 1 &, $812^{* *}$ \\
& Sig. (2-tailed) & &, 000 \\
& $\mathrm{~N}$ & 30 & 30 \\
Keterampilan smash & Pearson Correlation &, $812^{* *}$ & 1 \\
& Sig. (2-tailed) &, 000 & \\
& $\mathrm{~N}$ & 30 & 30 \\
\hline
\end{tabular}

Berdasarkan tabel 3 di atas Perhitungan menggunakan spss 25, dari data yang diambil Dari output diatas diketahui bahwa motivasi dengan keterampilan smash bola voli nilai signifikan $0,000<0,05$ dan nilai correlation 0,812 dan berhubungan positif. Maka Ho di tolak dan Hi diterima, yang berarti terdapat korelasi yang signifikan antara motivasi dengan dengan keterampilan smash bola voli.

Dasar Pedoman derajat hubungan koefisien Korelasi sebagai berikut :

a. nilai pearson correlation $0,00 \mathrm{~s} / \mathrm{d} 0,20=$ tidak ada korelasi.

b. nilai pearson correlation $0,21 \mathrm{~s} / \mathrm{d} 0,40=$ korelasi lemah.

c. nilai pearson correlation $0,41 \mathrm{~s} / \mathrm{d} 0,60=$ korelasi sedang.

d. nilai pearson correlation $0,61 \mathrm{~s} / \mathrm{d} 0,80=$ korelasi kuat.

e. nilai pearson correlation $0,81 \mathrm{~s} / \mathrm{d} 1,00=$ korelasi sempurna

Dari hasil pengolahan data motivasi (x) dengan keterampilan smash bola voli (y) nilai person correlation 0,812 dan termasuk kategori Korelasi kuat. Dalam hal ini motivasi siswa memberikan dukungan yang positif terhadap keterampilan smash bola voli. Sehingga hal tersebut dapat di artikan bahwa siswa yang memiliki motivasi tinggi dikatakan akan semakin mudah dalam mempelajari keterampilan smash bola dan cenderung memiliki tingkat keterampilan smash tinggi.

\section{Pembahasan}

Dari hasil pemaparan diatas, dapat disimpulkan bahwa hipotesis yang penulis ajukan sesuai dengan hasil penelitian, yaitu hipotesis diterima oleh karena itu, untuk mempelajari keterampilan smash bola voli akan semakin mudah, jika mempunyai motivasi yang tinggi dalam mempelajari keterampilan. Hal ini sesuai dengan teori yang oleh hamalik 2013 Dalam (Kompri, 2015)Menyatakan bahwa Motivasi sangat 
menentukan tingkat berhasil atau gagalnya perbuatan belajar siswa. belajar tanpa adanya motivasi kiranya akan sangat sulit untuk berhasil. Sebab, seseorang yang tidak mempunyai motivasi dalam belajar tidak akan mungkin melakukan aktivitas belajar. Hal ini merupakan pertanda bahwa sesuatu yang akan dikerjakan itu tidak menyentuh kebutuhannya.

Ahli yang lain mengemukakan menurut (Hidayat, 2009) bahwa motivasi adalah Aktulisasi energi psikologi yang dapat menggerakan individu untuk beraktivitas, sekaligus menjamin keberlanggsungan aktivitas tersebut, dan dan mennetukan arah aktivitas terhadap pencapaian tujuan.sedangkan menurut (Siagian, 2012); Motivasi merupakan akibat dari interaksi seseorang dengan situasi tertentu yang di hadapinya. Kemuadian Menurut Umboh 2017 dalam (Solihin \& Rachmawati, n.d.) Motivasi belajar adalah keseluruhan daya penggerak di dalam diri seseorang yang mampu menimbulkan semangat atau kegairahan belajar sedangkan menurut Komarudin (2017) Motivasi merupakan kecenderungan pada arah dan selektivitas dari tingkah laku yang di awasi dengan koneksinya pada konsekuensi, dan kecenderungannya untuk mempertahankan tujuan hingga tercapai.

Dari paparan di atas dapat di simpulkan bahwa motivasi merupakan rangsangan atau dorongan yang ada dalam diri masih-masih seseorang.yang secara aktif mendorong seseorang untuk melakukan sesuatu untuk memenuhi kebutuhannya. Motivasi mengandung makna sebagai kekuatan yang membuat seseorang terdorong untuk melakukan aktivitas tersebut untuk memenuhi kebutuhanya sendiri Dengan kata lain, motivasi adalah apa yang membuat kita berbuat, membuat kita tetap berbuat dan menentukan ke arena mana yang hendak kita perbuat.

Mengingat hal ini teramat penting karena jika di kaitkan dengan proses pembelajaran di sekolah. Yang menjadi sasaran utama pemberian motivasi oleh para guru kepada peserta didiknya adalah meningkatkan prestasi belajar dalam rangka pencapaian tujuan dan sasaran dalam pemebelajaran. Berdasarkan pendapat bebrapa pakar di atas penulis adapat mengambil kesimpulan bahwa motivasi mengandung makna sebagai kekuatan yang menyebabkan seseorang terdorong untuk malakukan aktivitas tertentu dalam rangka memenuhi kebutuhan. Sehingga kalau di kaitkan dengan penelitian ini adalah motivasi memberikan pengeruh terhadap keterampilan smash bola voli siswa di buktikan dengan hasil pengujian hipotesis dan ternyata hipotesis yang di ajukan peneliti secara signifikan dapat diterima.

Hasil penelitian menyatakan bahwa motivasi siswa berhubungan secara signifikan terhadap ketrampilan smash bola voli. Sesuai dengan hasil penelitian (Pasaribu 
\& Program, 2016); Hasil penelitiannya adalah dinyatakan bahwa pencapaian hasil belajar passing baw ah dipengaruhi adanya interaksi antara gaya mengajar dan motivasi belajar. Kemudian menurut penelitian yang lain Ayu Widhi Muchlisa (2017) Terdapat pengaruh motivasi terhadap keterampilan smash dengan nilai signifikansi 0,429. Dari beberapa hasil penelitian di atas dapat di simpulkan, bahwa terdapat hubungan yang positif dan signifikan antara motivasi terhadap prestasi belajar dan keterampilan Sehingga dapat disimpulkan pula bahwa motivasi berperan dalam meningkatkan suatu keberhasilan dalam keterampilan smash bola voli.

Berdasarkan hasil analisis penelitian dari data pengaruh motivasi terhadap keterampilan smash bola voli sebesar 66,0\% sedangkan 34,0\% lainya merupakan faktor lain yang tidak diteliti seperti disebutkan dalam faktor-faktor yang mempengaruhi keterampilan smash bola voli diantaranya sebagai berikut 1). Awalan melakukan smash 2). Loncatan 3). Pukulan 3).mendarat. persentase pengaruh motivasi terhadap keterampilan smash tergolong cukup tinggi yakti di atas 60,0\%.

\section{KESIMPULAN}

Berdasarkan analisis data, pengujian hipotesis, hasil dan pembahasan yang telah dikemukakan peneliti, maka dapat diambil kesimpulan terdapat hubungan yang signifikan antara motivasti dengan keterampilan smash dalam permainan bola voli di SMPN 1 Saguling dengan kriteria cukup tinggi. Berdasarkan hasil analisis penelitian dari data pengruh motivasi terhadap keterampilan smash bola voli sebesar $66,0 \%$ sedangkan $34,0 \%$ lainya merupakan faktor lain yang tidak diteliti seperti disebutkan dalam faktor-faktor yang mempengaruhi keterampilan smash bola voli diantaranya sebagai berikut 1). Awalan melakukan smash 2). Loncatan 3). Pukulan 3).mendarat. persentase pengaruh motivasi terhadap keterampilan smash tergolong cukup tinggi yakti di atas 60,0 \%. Dari hasil pengolahan data motivasi (x) dengan keterampilan smash bola voli (y) nilai person correlation 0,812 dan termasuk kategori Korelasi kuat. dalam hal ini motivasi siswa memberikan dukungan yang positif terhadap keterampilan smash bola voli. Sehingga hal tersebut dapat di artikan bahwa siswa yang memiliki motivasi tinggi dikatakan semakin mudah pula dalam mempelajari keterampilan smash bola voli yang cenderung memiliki tingkat keterampilan smash tinggi.

\section{DAFTAR PUSTAKA}

Achmad. (2016). Hubungan Antara Power Tungkai, Koordinasi Mata- Tangan, Dan Rasa Percaya Diri Dengan Hasil Keterampilan Open Spike Bola Voli. Jurnal Pendidikan Unsika, 4(1), 78-90. 
Hidayat, Y. (2009). Psikologi Olahraga. Cv.bintang warliartika.

Imawati, Clarry Sada, W. (2014). Upaya meningkatan keterampilan. November 2013, $57-62$.

Kemal. (2011). PENGARUH LATIHAN SKIPPING TERHADAP KEMAMPUAN SMASH DALAM PERMAINAN BOLA VOLI PADA SISWA PUTRA KELAS X SISWA SMA NEGERI 4 PALU KEMAL. 1, 1-13.

Kompri. (2015). Motivasi Pembelajaran. Pt. Remaja rosdakarya.

Pasaribu, A. M. N., \& Program. (2016). Program Studi Pendidikan Jasmani Kesehatan Dan Rekreasi Universitas Nusantara PGRI Kediri 1. Jurnal Sportif, 2(2), 1-14.

Pranopik, M. R. (2017). Pengembangan Variasi Latihan Smash Bola Voli. Jurnal Prestasi, 1(1), 31-33. https://doi.org/10.24114/jp.v1i1.6495

Primayanti, I. (2016). Perbedaan Pengaruh Metode Latihan Plyometrik dan Berbeban terhadap Peningkatan Kecepatan Smash Bolavoli Ditinjau dari Kekuatan Otot Lengan. Jurnal Pendidikan Olahraga Dan Kesehatan “GELORA, ” 3(ISSN: 23554355), 393-404.

Rohendi, A. (2019). Pengembangan Model Pembelajaran Passing Atas Bola Voli Berbasis Permainan Development of Passing Learning Model to Based Games Volley Ball. Journal of Physical and Outdoor Education, 1(1), 1-12.

Siagian, S. P. (2012). Teori Motivasi Dan Aplikasinya. Rineka Cipta.

Solihin, A. O., \& Rachmawati, A. (n.d.). Hubungan antara Jenis Kelamin dan Usia dengan Motivasi Belajar Renang Relationship between Gender and Age with Motivation to Learn Swimming. 1(2).

Sugiarto. (2012). Metode penelitian pendidikan. Alfabeta Bandung.

Sugiono. (2014). Metode Penelitian Pendidikan. Alfabeta Bandung.

Sugiono. (2015). Metode Penelitian Tindakan Komprehensif. Alfabeta Bandung.

Sulistiadinata, H. (2020). Meningkatkan keterampilan passing atas bola voli melalui media pembelajaran menggunakan alat bantu Improve volleyball passing skill though learning media using assistive devices. Journal of Physical and Outdoor Education, 2(2), 207-220.

Yuniawan, A. E. (2012). Modifikasi Model Pembelajaran Bola Voli Melalui Permainan Bola Voli Mini Berlapis. ACTIVE: Journal of Physical Education, Sport, Health and Recreation, 1(4). https://doi.org/10.15294/active.v1i4.517 